\title{
Designing Calculus Teaching Model Based on STEM for University Students: Is It Valid, Practice, and Effective?
}

\author{
Sahrul Syawal", Patta Bundu, Anshari \\ Postgraduate of Universitas Negeri Makassar, South Sulawesi, Indonesia
}

Received April 8, 2021; Revised May 30, 2021; Accepted June 20, 2021

\section{Cite This Paper in the following Citation Styles}

(a): [1] Sahrul Syawal, Patta Bundu, Anshari, "Designing Calculus Teaching Model Based on STEM for University Students: Is It Valid, Practice, and Effective?," Universal Journal of Educational Research, Vol. 9, No. 7, pp. 1452 1463, 2021. DOI: 10.13189/ujer.2021.090711.

(b): Sahrul Syawal, Patta Bundu, Anshari (2021). Designing Calculus Teaching Model Based on STEM for University Students: Is It Valid, Practice, and Effective?. Universal Journal of Educational Research, 9(7), 1452 - 1463. DOI: 10.13189/ujer.2021.090711.

Copyright $\mathrm{C} 2021$ by authors, all rights reserved. Authors agree that this article remains permanently open access under the terms of the Creative Commons Attribution License 4.0 International License

\begin{abstract}
One of the lecturers' duties apart from teaching is to develop learning products that are used to overcome various problems encountered during the learning process. For that reason, each lecturer must develop their learning model so that learning objectives can be adequately achieved. The large number of lecturers who only use ready-made teaching materials has an impact on student learning outcomes, which are still low. This can be understood because, in essence, the learning problems faced by students are different. This study aims to determine the level of validity, practicality, and effectiveness of the developed STEM-based calculus learning model in tertiary institutions. This study is part of research and development focused on the trial phase, which includes testing the validity, practicality, and effectiveness. This research was conducted at the Indonesian Christian University of Toraja, Makassar, Indonesia, with participants consisting of 5 validators/experts, two lecturers, and 20 students. Data collection was carried out using learning outcome tests, validation sheets, lecturer response questionnaires, teacher response questionnaires, and observation sheets. The data that have been collected are then analyzed using quantitative analysis techniques using SPSS version 20. The results show that the STEM-based calculus learning model that has been developed is proven to be valid, practical, and effective to improve students' learning outcomes.
\end{abstract}

Keywords Calculus Learning Model, STEM, Validity, Practicality, Effectiveness

\section{Introduction}

STEM is an issue that is still being discussed in the academic realm. In fact, in the last decade, we have seen a massive movement in education related to STEM education \& learning (Science, Technology, Engineering, and Mathematics) [1]. This is understandable because STEM is an integrated 21st-century skill, and one of them is related to mastery of technology [2]. David \& Kebritchi [3] stated firmly that the proliferation of studies on STEM education was none other than its role in work in the current era of the industrial revolution 4.0.

The STEM issue associated with education is based on the fact that there has been a decrease in the number of young people interested in science, technology, engineering and mathematics. This fact was also released to the public by the Organization for Economic Cooperation and Development [4]. It states that the decline in interest in these fields has occurred in the United States since the 1970s. In connection with the increasingly fierce global economic competition around the world, policymakers in each country are interested in finding solutions so that more young people will like these various fields. One of them is by adopting a STEM education policy that applies to all education levels [5].

The definition of STEM is still interpreted differently, and it is not clear. This is due to factors that suggest that 
STEM learning is an extensive learning area and includes many epistemological and practical disciplines [6]. However, the identification related to the qualifications in STEM itself is relatively clear [7]. STEM education is defined as an integrated learning environment in which students study more than one discipline, namely science, technology, engineering, and mathematics [8]. McCaslin [9] emphasized that STEM learning is an integrated learning system that provides a meaningful learning environment to increase students' knowledge and understanding in related fields.

Apart from getting a job, mastery of STEM for young people also has various benefits. In several studies, STEM learning is believed to increase student interest, motivation and creativity [10]. Other studies have shown that STEM learning also positively impacts attitudes, communication skills, and problem-solving abilities [11]. STEM learning can also be aimed at improving entrepreneurship attitudes for students [12]. Learning with the STEM approach not only discusses competencies in these four aspects but also emphasizes that it is no longer enough for modern citizens to only understand one area. This means that a current citizen of the world must master integrated knowledge and skills, especially technology and engineering [13]. STEM-based learning can also encourage innovation through design activities and create solutions to problems in the real world [14]. Margot \& Kettler [15] emphasized that everyone should be able to use today's real-world challenges as an entry point for integrating STEM disciplines.

In Indonesia, the socialization and application of STEM into learning continue to be encouraged, starting from elementary schools and middle schools to tertiary levels. Apart from going through curriculum policies, the STEM approach is also suggested to be implemented integratively through courses. One of the courses can be applied with the STEM approach in mathematics, especially in calculus mathematics. This subject can be said to be one of the most complex and dynamic lessons. Calculus mathematics is not only a mastery of concepts (remembering) but also includes the ability to develop reasoning and problem-solving skills [16].

There is a lot of research related to calculus courses in tertiary institutions integrated into the STEM approach. Magsino [17] found that math games positively impacted students' STEM computational competence in introductory calculus courses. A different study stated that the homework model with online or handwritten methods did not significantly differ in the subjects of STEM-based calculus [18]. Barroso [19] examined a mathematical model used to predict students' retention in pre-calculus courses with a different topic. On the other hand, Li \& Schoenfeld [20] stated that there needs to be an alternative approach in changing the stigma that mathematics is the cause of the number of students who are no longer interested in the STEM field. The method referred to is learning calculus mathematics which is linked to STEM education. On a local research scale in Indonesia, Sulistiawati et al. [21] stated that students positively responded to STEM integrated learning to improve mathematical literacy.

There are still research gaps in the development of learning models from several studies on STEM-based calculus learning above. Much research has focused on problems in the context of proving something. In other words, many lecturers use teaching materials that are available in the market. But unfortunately, they do not realize that the textbooks they use do not necessarily match the needs of their students. A lecturer must create his learning model tailored to his students' issues and characteristics [22]. Learning models can be made using research and development designs that involve lecturers and students together [23], [24].

This study is the final phase in research and development to testing the validity, practicality, and effectiveness of the STEM-based calculus learning model developed. These three tests are used in determining whether the product. That has been developed is suitable for use and disseminated to the public. Therefore, the formulation of the problem in this study is the level of validity, practicality, and effectiveness of the STEM-based calculus learning model developed.

\section{Literature Review}

\subsection{Education of Science, Technology, Engineering, and Mathematic (STEM)}

STEM is an acronym for science, technology, engineering, and mathematics. The term was first coined by the National Science Foundation (NSF) of the United States (US) as the education reform movement's theme to grow the workforce in STEM fields. This movement also aims to develop STEM literate citizens and increase the United States' global competitiveness in science and technology innovation [25]. This STEM-based education reform aims to tackle the number of world citizens, especially children who do not like the STEM field. This is because, starting in the 1970s, the number of people who chose STEM as a job or a choice of majors in higher education has decreased.

In general, the STEM education overview aims to transform teaching practices from traditional lecture-based teaching to inquiry-based, project-based, problem-based learning as a means of presenting an interdisciplinary, meaningful learning experience [26], [27]. STEM education is an approach to education in which Science, Technology, Engineering, Mathematics is integrated with the educational process focusing on solving problems in real everyday life and professional life. STEM education shows students about the concepts, principles, techniques 
of science, technology, engineering and mathematics (STEM) used in an integrated manner to develop products, processes, and systems beneficial to human life [28].

Stohlmann et al. [29] listed the top ten lessons for teaching mathematics and science: (1) manipulative and hands-on learning; (2) cooperative learning; (3) discussion and inquiry; (4) questions and allegations; (5) critical thinking; (6) writing for reflection and problem solving; (7) using a problem-solving approach; (8) integrating technology; (9) the teacher as a facilitator; (10) using assessment as part of the learning process. In line with Stohlmann's thinking, some experts argue that STEM learning can also be designed with cooperative learning methods and discussions, asking questions, exploring, investigating various tasks, and applying the knowledge they have [30]-[32].

STEM is a field that requires numeracy skills, critical understanding and analysis, understanding of scientific principles and mathematics [33], [34]. For that reason, an appropriate learning strategy is needed so that STEM learning can run well. One way is to integrate STEM into subjects. An integrated STEM learning environment can occur in a course or program through direct problem solving [35].

\subsection{Validity, Practicality, and Effectiveness}

In research and development, an important aspect that must be prioritized is the testing phase of the product that has been developed. This is the basis for determining how strong the feasibility of the product is before it is disseminated. According to Nieven [36] here are three types of tests used to see the product's quality developed: validity, practicality, and effectiveness. The validity test aims to measure the validity level of the experts. The practicality test aims to see the product's practicality level developed from users' perspective, both teachers and students. On the other hand, effectiveness tests are carried out to see to what extent the product can improve learning outcomes or the product's targeted aspects.

Validity can be defined as a measure to see how well the data collected covers the actual area of investigation [37]. In line with this statement, Field [38] states that validity measures what one should want to calculate based on predetermined aspects. In general, the validity test can be grouped into four parts, namely face validity, validity criteria, content validity, and construct validity [39].

A practicality test is a type of test that involves users, both teachers and students. These users are asked to respond to products that have been developed through questionnaires or other instruments. Practicality test is a test that tests practicality according to the context and usage [40]. The practicality criteria used in this test can be divided into two types, namely: (a) the product developed can be applied according to the judgment of experts and practitioners and (b) the product developed can be applied in real terms in the field [36].

The final test in measuring the quality of the development product is the effectiveness test. This test can be viewed from the consistency between the design/learning objectives with students' experience and learning outcomes. That is, with the effectiveness test, a description of the desired learning outcomes can be obtained [36].

Kadir et al. [41] stated that an effective assessment is an assessment that considers the effect of assessing student behaviour and learning outcomes. Also, effectiveness can be viewed from the relationship between learning outcomes and the curriculum, aspects of the assessment structure on subjects, and feedback [42].

\subsection{Calculus Learning}

The term Calculus comes from Latin, namely calculus which means small stone or to count. Calculus is a branch of mathematics that includes limits, derivatives, integrals, and infinite series. Calculus is also defined as a change, as geometry is the science of shapes, and algebra is the science of solving equations and their applications. Calculus has wide applications in science, economics, and engineering; and can solve various problems that cannot be solved with elementary algebra. Calculus has two main branches, differential calculus and integral calculus, interconnected utilizing calculus's fundamental theorems. Calculus lessons are the gateway to other higher mathematics courses, specifically study functions and limits, which is generally called mathematical analysis [43].

According to Aditia et al. [44] the fundamental theorem of calculus explains the relationship between two central operations of calculus: differentiation and integration. Calculus has one of the most challenging concepts for students to understand and master. Although most learners learn the specific algorithms and completion procedures taught to them, their general conceptual understanding often remains very poor [16].

The goal of learning calculus mathematics is to master the material and develop reasoning and problem-solving. Thus, lecturers' role in learning calculus mathematics is concerned with the final result and needs to develop students' reasoning abilities. Lecturers can cultivate reasoning skills by training students to write mathematical reasons to solve math problems. In line with this, lecturers who cover calculus mathematics are oriented towards mastering the material and developing reasoning. This means that just learning mathematics material is not enough to become a qualified mathematics lecturer or student.

\subsection{Teaching Model}

The learning model is a theory-based analytical 
characterization of the educator's actions that explains how and why an educator should make the choices he or she makes while teaching [20]. The concept of the learning model, according to Afandi et al. [45] is a plan or pattern that is used as a guide in planning classroom lessons or tutorial lessons. The learning model refers to the learning approach used, including teaching objectives, stages in learning activities, learning environment, and class management.

Teaching models are also defined as strategies based on the theory (and often research) of educators, psychologists, philosophers, and others that question how individuals learn. Each model consists of reasons, a series of steps (actions, behaviours) that teachers and students must take, a description of the necessary support systems, and methods for evaluating the progress of students [46], [47]. On the other hand, the learning model is also defined as a plan or a pattern used as a guide in planning classroom learning or tutorial learning and determining learning tools, including books, films, computers, curricula, and others [47]. In essence, each learning model directs us in designing learning in helping students achieve targeted learning goals.

In connection with the importance of an innovative learning model, a lecturer should develop and create their learning model tailored to the needs and characteristics of students. One way to do this is by researching with a research \& development design to find problems in the field, followed by creating learning products to overcome these problems. The learning model is considered essential to be developed because it is the most significant element that includes guidance for lecturers and other learning tools.

\section{Method}

\subsection{Research Design, Context \& Participants}

This research is part of the research and development process, emphasising the development phase, namely the testing phase of the validity, practicality, and effectiveness of the STEM-based calculus learning model for students. The research and development design adopted in this study is the ADDIE MODEL (Analysis, Design, Development, Implementation, \& Evaluation). Reiser and Molenda developed this model, which is also widely applied to curriculum development activities [48]. This article is focused on examining the development phase, namely, testing the validity, practicality, and effectiveness of the STEM-based calculus learning model.

The research was conducted at the Indonesian Christian University (UKI) Toraja, Makassar, Indonesia, involving three groups of participants, namely: (a) 5 experts/validators, (b) 2 calculus/mathematics lecturers, and (c) 20 students. The Indonesian Christian University Toraja is a leading private campus in Tana Toraja, South Sulawesi, Indonesia, which has various faculties, one of which is the Teacher Training \& Education Faculty. One of the things that underlie this research is the low learning outcomes of students in the Mathematics Education study program Calculus at the campus. For this reason, research \& development is carried out to create a learning model that can improve learning outcomes for the Calculus course.

Furthermore, the sampling technique used to determine the number of samples (20 students) was the purposive sampling technique. This technique is a sampling technique that selects the number of research samples based on specific reasons. Finally, the research design used in the effectiveness test phase was the pretest-posttest control group design by providing treatment between the pretest and posttest sessions.

\subsection{Data Collection}

Based on the formulation of the problem in this study, data collection techniques are divided into three types, namely: (1) questionnaire, (2) observation, and (3) test. The questionnaire technique consisted of a lecturer response questionnaire, a student response questionnaire, and a questionnaire in the form of a validation sheet addressed to experts. Furthermore, the observation technique used in this study was a learning implementation observation checklist filled in by the observers during the learning process. Finally, the test technique used is multiple choice tests to determine student learning outcomes in both the pretest and posttest sessions. However, specifically, data collection can be divided into three groups, namely: (1) data collection for validity testing, (2) data collection for practicality tests, and (3) data collection for effectiveness testing.

To test the validity level of this learning model, researchers used two types of validation sheets, namely validation sheets for learning products and validation sheets for research instruments. This validation sheets are designed according to needs using a Likert scale using four answer choices. Learning product validation sheets in question include: (1) model book validation sheets, (2) lecturer handbook validation sheets, (3) semester lesson plan/syllabus validation sheets, and (4) modules. Furthermore, the validation sheet for the research instrument was: (1) validation of the learning implementation sheet, (2) validation of the lecturer response questionnaire, and (3) validation of the student response questionnaire. The questionnaire form of a validation sheet is given to the experts after the product prototype has been designed.

Also, to measure the practicality of this learning model, researchers used several instruments that had been validated previously, namely: (a) learning implementation sheets, (b) lecturer response questionnaires, and (c) student response questionnaires. The results of the validation of the three instruments were reviewed at the beginning of the research results. The observation sheet 
for implementing learning was given to two observers each time the treatment was carried out using the STEM-based calculus learning model. In addition, a questionnaire instrument was provided by researchers to lecturers and students at the last learning meeting to find out their assessment of the learning model.

Furthermore, the researcher used a research instrument in the form of a multiple-choice test to measure the effectiveness of the learning model that had been developed. The test consists of 10 items of the matrix material, ten items of derivative material, and ten items of integral material. These questions were divided into two groups, namely 15 questions for the use of logic and 15 questions for problem-solving skills. This learning outcome test was carried out twice, namely in the pretest and posttest sessions. Before being used, the learning outcome test was tested for validity and reliability by involving 17 students as the research sample. The test results stated that the learning outcome test was valid and reliable because the calculated $\mathrm{r}$ score was more significant than the $r$ table $(0.976>0.482)$.

\subsection{Data Analysis}

\section{(1) Validity Test}

The data collected from five validators were analyzed to determine their cumulative mean score. The mean total score is obtained using the formula:

$$
(\bar{X})=\frac{\sum \overline{A_{i}}}{n}
$$

Information:

$$
\begin{gathered}
(\bar{X})=\text { total average } \\
\overline{A_{i}}=\text { Aspect average } \mathrm{i} \\
n=\text { number of aspects }
\end{gathered}
$$

After the cumulative average score of each learning product has been determined, the researcher then compares it with the validity category table to decide its validity level. The validity category consists of four groups: very valid, valid, less valid, and invalid. The score interval in determining the validity level category can be seen in table 1.
Table 1. The categories of the validity of the learning model by Ahmar \& Rahman [49]

\begin{tabular}{|c|c|c|}
\hline No. & Criteria & Category \\
\hline 1. & $3,5 \leq \mathrm{M} \leq 4,0$ & Very valid \\
\hline 2. & $2,6 \leq \mathrm{M}<3,5$ & Valid \\
\hline 3. & $1,6 \leq \mathrm{M}<2,5$ & Less valid \\
\hline 4. & $1<1,5$ & unvalid \\
\hline
\end{tabular}

\section{(2) Practicality test}

During the learning process, lecturers and students participate in responding to the STEM-based calculus learning model. After both response data were collected, the researcher analyzed the data to determine the cumulative average score. The formula used in finding the overall average score is:

$$
\overline{A_{i}}=\frac{\sum_{m=1}^{t} A_{m l}}{t}
$$

Information:

$$
\overline{A_{i}}=\text { the average aspect value } \mathrm{i}
$$

$$
\begin{gathered}
\mathrm{A}_{\mathrm{mi}}=\text { average aspect of the } \mathrm{i} \text { meeting } \mathrm{m} \\
\mathrm{t}=\text { number of meeting }
\end{gathered}
$$

Table 2. Categories of feasibility/practicality of calculus learning models by Yahya, Munoto \& Soeryanto [50]

\begin{tabular}{|c|c|c|}
\hline No & Criteria & Category \\
\hline 1. & $3.5 \leq \mathrm{M} \leq 4.0$ & Very good \\
\hline 2. & $2.5 \leq \mathrm{M}<3.5$ & good \\
\hline 3. & $1.5 \leq \mathrm{M}<2.5$ & Not good \\
\hline 4. & $0.0 \leq \mathrm{M}<1.5$ & Poorly \\
\hline
\end{tabular}

\section{(3) Test the effectiveness}

The learning outcome data that have been collected, both in the pretest and posttest sessions, are analyzed to determine whether there is an effect of the learning model on student learning outcomes using SPSS 20. The results of data analysis were compared with the normative standard of learning outcomes categories consisting of: (a) high category, (b) high enough, and (c) low category. The categorization of learning outcomes can be seen in table 3 .

Table 3. Normative standards for calculus learning outcomes category by Azwar [51]

\begin{tabular}{|l|l|}
\hline The normative standard of value categories & Value category description \\
\hline Data on the value of learning outcomes $\geq$ Mean $+1.0(\mathrm{SD})$ & The value of learning outcomes is high \\
\hline Mean $+1.0(\mathrm{SD})>$ Data $<$ Mean $-1.0(\mathrm{SD})$ & The value of learning outcomes is quite high \\
\hline Data on the value of learning outcomes $\leq$ Mean $-1.0(\mathrm{SD})$ & Low learning outcomes \\
\hline
\end{tabular}




\section{Results}

\subsection{Level of Validity}

As discussed in the method section, this validity test is grouped into two parts: the validity test for product development and the validity test for research instruments. Both tests were carried out by asking for responses from 5 experts. Data analysis results from experts for the validity of products. Research instruments can be seen in table 4 and table 5 .

Table 4. Recapitulation of product validation results

\begin{tabular}{|c|c|c|c|}
\hline \multirow{2}{*}{ No. } & Validated product & \multicolumn{2}{|c|}{ Validity } \\
\cline { 3 - 4 } & Average & Category \\
\hline 1. & $\begin{array}{c}\text { Calculus learning model } \\
\text { book }\end{array}$ & 3.43 & Valid \\
\hline 2. & Lecturer manual & 3.33 & Valid \\
\hline 3. & $\begin{array}{c}\text { Semester learning } \\
\text { plan/syllabus }\end{array}$ & 3.33 & Valid \\
\hline 4. & Modul & 3.45 & Valid \\
\hline \multicolumn{2}{|c|}{ Total average } & $\mathbf{3 . 3 8 5}$ & Valid \\
\hline
\end{tabular}

From table 4 above, information is obtained that the overall average score of the products developed by both the model book and the learning tools is 3,385 . The validation score of the STEM-based calculus learning model book is 3.43 , the lecturer handbook is 3.33 , the Semester Learning Plan/syllabus is 3.33, and the calculus learning module is 3.45 . Thus it can be concluded that the model book and calculus learning tools based on STEM are in the "valid" category. This conclusion is obtained by comparing the overall average score with the table of validity criteria reviewed in the research methods section. The valid category is determined because the average score of 3.385 is in the range of $2.6 \leq \mathrm{M}<3.5$.

Table 5. Recapitulation of the results of the research instrument validation

\begin{tabular}{|c|c|c|c|}
\hline \multirow{2}{*}{ No. } & Validated instrument & \multicolumn{2}{|c|}{ Validity } \\
\cline { 3 - 4 } & Average & Category \\
\hline 1. & $\begin{array}{c}\text { Model implementation } \\
\text { observation sheet }\end{array}$ & 3.67 & Very valid \\
\hline 2. & $\begin{array}{c}\text { Questionnaire for lecturer } \\
\text { responses }\end{array}$ & 3.7 & Very valid \\
\hline 3. & $\begin{array}{c}\text { Questionnaire for student } \\
\text { responses }\end{array}$ & 3.6 & Very valid \\
\hline & Total average & $\mathbf{3 . 6 6}$ & Very valid \\
\hline
\end{tabular}

Furthermore, the validity test for the research instrument is presented in table 5 above. From the table, information is obtained that the three instruments obtained a cumulative average score of 3.66 . The observation sheet of learning feasibility got an average score of 3.67, the lecturer response questionnaire was 3.7 , and the student response questionnaire was 3.6. Thus, it can be concluded that the three research instruments are categorized as very valid. This category is determined after comparing the average score with the previously reviewed validity category table. The instrument was declared very valid because the cumulative average score was 3.66 in the score range of $3.5 \leqslant \mathrm{M} \leqslant 4.0$.

\subsection{Practicality Test Results}

(1) The results of observations of the implementation of the learning model

Table 6. Observations of the implementation of the learning model from 2 observers

\begin{tabular}{|c|c|c|c|c|c|c|}
\hline \multirow{2}{*}{ Aspect } & \multicolumn{4}{|c|}{ Meeting } & \multirow{2}{*}{ Average } & \multirow{2}{*}{ Kategori } \\
\hline & 1 & 2 & 3 & 4 & & \\
\hline $\begin{array}{l}\text { Model } \\
\text { syntax }\end{array}$ & 3.25 & 3.5 & 3.5 & 3.5 & 3.43 & Good \\
\hline $\begin{array}{l}\text { Social } \\
\text { system }\end{array}$ & 3.0 & 3.2 & 3.2 & 3.6 & 3.25 & Good \\
\hline $\begin{array}{l}\text { Reaction } \\
\text { principle }\end{array}$ & 3.38 & 3.78 & 3.63 & 3.75 & 3.53 & $\begin{array}{l}\text { Very } \\
\text { Good }\end{array}$ \\
\hline $\begin{array}{c}\text { Support } \\
\text { system }\end{array}$ & 3.2 & 3.4 & 3.2 & 4.0 & 3.45 & Good \\
\hline $\begin{array}{c}\text { Total } \\
\text { average }\end{array}$ & 3.2 & 3.36 & 3.38 & 3.72 & 3.41 & Good \\
\hline
\end{tabular}

Table 6 above is a description of the average score observed by two observers during four learning meetings. The average score obtained from the observations starting from the syntax of the model is 3.43 . The average score obtained is in the interval $2.5 \leq \mathrm{M}<3.5$, so the model's syntax aspect is said to be carried out well. At the first meeting, there were still components of the syntax that had not been implemented due to the lack of understanding of the learning model's syntax implementation in calculus material. In the aspect of the social system, the implementation of the assessment at the trial stage during four meetings with two observers, the average score obtained from the observations is 3.25 , which is located at an interval of $2.5 \leq \mathrm{M}<3.5$, then this aspect of the social system is carried out well.

Implementation in the principle of reaction, the mean total score obtained from the observation is 3.5 . It is located at the interval $3.5 \leq \mathrm{M} \leq 4.0$, so this aspect is included in the very good category. At the first meeting, the value of this aspect was still in the good category due to a lack of understanding of the learning model's implementation. Furthermore, in the support system aspect, the implementation of the trial stage assessment during four meetings of two observers, the average score obtained was 3.45 and was in the interval $2.5 \leq \mathrm{M}<3.5$, then the aspect of the support system was carried out well. Based on these results, the total mean of all aspects starting from syntax, social systems, reaction principles, and support systems, the cumulative observation score results in a value of 3.41. It lies in the interval $2.5 \leq \mathrm{M}<$ 3.5 and is considered in the "good/practical" category. 


\section{(2) Analysis of the results of the lecturer response questionnaire}

Table 7. The results of the lecturer response questionnaire analysis

\begin{tabular}{|c|c|c|c|}
\hline No & The assessment aspect & $\begin{array}{c}\text { Average } \\
\text { score }\end{array}$ & Category \\
\hline 1. & Learning Media & 3.2 & Good \\
\hline 2. & Serving eligibility & 3.4 & Good \\
\hline 3. & Language & 3.5 & Very Good \\
\hline 4. & Assessment & 3.67 & Very Good \\
\hline & Cumulative average & $\mathbf{3 . 4 4}$ & Good \\
\hline
\end{tabular}

Based on the results of the data analysis of the lecturers' response validation as in table 7 above, it can be concluded that the overall average score is 3.44 and is included in the good / practical category. This is based on the average score for each aspect that is included in the high category. The learning instrument aspect obtained a score of 3.2, the feasibility of presentation was 3.4, the language aspect was 3.5 , and the assessment aspect was 3.67. Overall, the average score for the validation of the lecturers' questionnaire responses was 3.44 and was categorized as good/practical. This indicates that the calculus learning model with the STEM approach has a good reply and is applicable to use.

\section{(3) The results of the student response questionnaire analysis}

Table 8. Results of student response data analysis

\begin{tabular}{|c|c|c|c|}
\hline No & The assessment aspect & Average score & Category \\
\hline 1. & Theory & 3.51 & Very Good \\
\hline 2. & Learning process & 3.44 & Good \\
\hline 3. & Language & 3.26 & Good \\
\hline 4. & Evaluation & 3.43 & Good \\
\hline 5. & Benefits & 3.5 & Very Good \\
\hline & Cumulative average & $\mathbf{3 . 4 3}$ & Good \\
\hline
\end{tabular}

Based on the results of table 8 , it can be explained that 20 students became respondents in filling out the student response questionnaire about this calculus learning model. The questionnaire was distributed to students after the STEM-based calculus learning was completed. The student response questionnaire was designed not to include specific student identities but only asked for general information from the participants such as the respondent number (filled in by the researcher), gender, and respondent age.

From table 8 , information is obtained that the results of student responses are in the material aspect. The average score obtained is 3.51 and is located in a very good category interval and the benefit aspect, which has a mean score of 3.5. Furthermore, the learning process aspect has a score of 3.44. Likewise, it is in a good category with the language and evaluation aspects, which respectively have a score of 3.26 and 3.43, which are in the good category interval.

Therefore, from the mean results of all aspects, the value is 3.43 . This value is attached to the good category. Thus, most of the 20 respondents surveyed stated that the calculus learning model with the STEM approach was good and exciting because students were happy with the lecturers' method of providing learning using these learning models and tools. In conclusion, this STEM-based calculus learning model is generally of good quality and attracts students' attention.

\subsection{The Level of Effectiveness of the Calculus Learning Model}

The test carried out in measuring student learning outcomes in the calculus learning model with the STEM approach is the paired sample $t$-test. This learning outcome test was carried out twice, namely, pretest and posttest. The pretest session was carried out at the beginning of the lesson, while the posttest session was carried out after the students received treatment using the STEM-based calculus learning model. There are 30 multiple choice questions given to students giving a score of 1 for the correct answer and 0 for the wrong answer, then converted to a scale score of 100 . To find out the respective frequency distribution and the results of the t-test statistical analysis are shown in Table 9.

Table 9. Paired Samples Statistics

\begin{tabular}{|cc|c|c|c|c|}
\hline & Mean & N & $\begin{array}{c}\text { Std. } \\
\text { Deviation }\end{array}$ & $\begin{array}{c}\text { Std. Error } \\
\text { Mean }\end{array}$ \\
\hline Pair 1 & Pretest & 58.6666 & 20 & 9.51449 & 2.12750 \\
\hline & Posttest & 71.6666 & 20 & 10.23133 & 2.28779 \\
\hline
\end{tabular}

Table 9 shows that the data analysis output displayed summarises the results of descriptive statistics from the two samples studied, namely the pretest and posttest values. For the pretest value, the mean average score was 58,666, while in the posttest session, the score was 71,666. Furthermore, the standard deviation of the pretest is 9,514, and the posttest is 10,231 . The pretest means standard error value is 2.128 , and the mean posttest standard error is 2.288. From the results of the analysis, the pretest means the value was $58.50<$ posttest 71.35 . Thus, it can be concluded that descriptively there is a difference in the mean pretest and posttest.

Table 10. Paired sample correlations

\begin{tabular}{|l|c|c|c|}
\hline & N & Correlation & Sig. \\
\hline Pair 1 pretest \& posttest & 20 & .925 & .000 \\
\hline
\end{tabular}

To prove the mean difference between the pretest and posttest was significant, the researchers interpreted the paired sample test. Based on the output as in table 10 above, it is known that the correlation coefficient value is 0.925 with a significant value of $0.00<0.05$ probability. Thus, it can be concluded that there is a relationship between the pretest variable and the posttest variable. 
Table11. Paired samples test

\begin{tabular}{|c|c|c|c|c|c|c|c|c|}
\hline & \multicolumn{3}{|c|}{ Paired differences } & & & \multirow{3}{*}{$\mathbf{T}$} & \multirow{3}{*}{ df } & \multirow{3}{*}{$\underset{\text { Sig. }}{\text { (2-tailed }}$} \\
\hline & \multirow{2}{*}{ Mean } & \multirow{2}{*}{ Std. deviation } & \multirow{2}{*}{ Std. error mean } & \multicolumn{2}{|c|}{$\begin{array}{l}95 \% \text { confidence interval } \\
\text { of the difference }\end{array}$} & & & \\
\hline & & & & Lower & Upper & & & \\
\hline $\begin{array}{c}\text { Pair 1 } \\
\text { pretest-posttest }\end{array}$ & -13.00005 & 3.88439 & .86858 & -14.81800 & -11.18210 & -14.967 & 19 & .000 \\
\hline
\end{tabular}

$\mathrm{H}_{0} \quad$ : There is no mean difference between pretest and posttest results

$\mathrm{H}_{1} \quad$ : There is a difference in the average pretest and posttest results

Guidelines for making decisions on paired samples test based on significant values are as follows:

1. If the value is Sig. (2-tailed) $<0.05$ then $\mathrm{HO}$ is rejected, and $\mathrm{H} 1$ is accepted

2. Conversely, if the value is Sig. (2-tailed) $>0.05 \mathrm{H} 0$ is accepted, and $\mathrm{H} 1$ is rejected

Based on table 11, the Paired Samples Test output has a known sig value. (2-tailed) of $0.00<0.05$, then $\mathrm{H} 0$ is rejected or, in other words, accepts $\mathrm{H} 1$, that is, there is a difference in the average pretest and posttest, which means that there is an effect of using the calculus learning model with the STEM approach in improving student learning outcomes. Based on the output of the Paired Samples Test, it contains information on the mean Paired Differences of -13.00005 . This value shows the difference between the average pretest and posttest 58,666-71,666 = $-13,005$. Thus, the difference between the difference is $-11,818$ to $-11,182(95 \%$ Confidence Interval of the Difference lower and upper).

Table 12. Categories of calculus learning outcomes using the STEM approach

\begin{tabular}{|c|c|c|c|}
\hline Category & Skor interval & Frekuensi & Percentage \\
\hline High & $\begin{array}{c}\text { Data on the value of } \\
\text { learning outcomes } \geq \\
76.784\end{array}$ & 6 & $30 \%$ \\
\hline $\begin{array}{c}\text { High } \\
\text { Enough }\end{array}$ & $76.784>$ data $<53.549$ & 11 & $55 \%$ \\
\hline Low & $\begin{array}{c}\text { Data on the value of } \\
\text { learning outcomes } \leq \\
53.549\end{array}$ & 3 & $15 \%$ \\
\hline Total & & 20 & $100 \%$ \\
\hline
\end{tabular}

In addition to testing student learning outcomes with the t-test, in table 12, researchers also analyzed the test results by grouping them into predetermined categories in the methods section. From the data in table 12 above, it can be seen that there are $30 \%$ of students (6 students) get scores in the high category. Furthermore, as many as 55\% (11 students) of students scored in the high enough category, while $15 \%$ (3 people) scored in the low category.

\section{Discussion}

This calculus learning model with the STEM approach has been designed based on a needs analysis and then tested to get the level of validity, practicality, and effectiveness. These three tests are a way of determining the quality level of the product that has been developed [36]. From the validation and practicality test results, the prototype learning model was revised based on experts and lecturers' suggestions as users. Furthermore, in the final stage, an effectiveness test is carried out to see to what extent these products can affect student learning outcomes.

The product validity test is usually carried out by asking for an assessment from experts in terms of content, language, and presentation. According to Rogayan \& Dollete [52] several assessment aspects in validation tests are usually varied and tailored to needs. According to him, in general, the aspects assessed are: (a) adequacy, (b) coherence, (c) suitability, and (d) utility. The calculus learning model prototype is given to the validator then the assessment data is analyzed to determine the average score. This calculus learning model was declared valid based on two experts' assessment with an average total score of 3,385. In general, the validation test is carried out on two aspects, namely content validity and construct validity [53]. In this study, content validity is the type of validity chosen to assess a learning model's components based on cutting-edge knowledge. The content validity also highlights the need to develop and design the current model or device [54].

The results of this study indicate that the STEM-based calculus learning model is proven to be practically based on the perspectives of lecturers and students. Furthermore, they agree that this learning model has various practical aspects, such as easy understanding, choosing the correct language, etc. Furthermore, Jaedun et al. [55] state that the product development results are declared practical if the lecturer assessment states that the product can be applied with minor revision. The development product can be implemented in the field because it is by the applicable curriculum, time allocation, and educational institutions' condition. 
The level of effectiveness of the learning model in this study also shows a potential effect of using this model on students' learning outcomes. That is, there is an increase in student learning outcomes after using this learning model. The effectiveness of learning products is determined by three criteria, namely: (a) the achievement of predetermined goals, (b) according to the needs of users, and (c) having a positive impact on improving learning outcomes, both in the aspects of knowledge, attitudes, and behaviour [56]. The results of this study are in line with and supported by the results of previous studies, which state that technology and information-based learning models (part of STEM) can help convey material in more detail and attract students' attention [57]. In addition, using the calculus learning model with the STEM approach is more accessible and less draining, and its utilization is no longer limited by space and time [58]. That is, learning mathematics with the STEM approach is very effective because: (a) it can facilitate and expand access to information in learning because it uses computers and internet access, (b) can help visualize abstract material, (c) can display material learning is more interesting and (d) allows interaction with the material being studied.

Many researchers, teachers, and lecturers have conducted studies on STEM. In addition to improving learning outcomes, the STEM approach that is integrated into courses/subjects also impacts other aspects. Chiang \& Lee [59] reported that STEM learning blended into a project learning strategy could improve learning motivation and solve problems. The implementation of STEM learning is also considered to increase students' feelings of self-efficacy [60], [61]. In other studies, STEM learning has also been shown to have a positive effect on (a) disciplinary adoption \& student career awareness [62], (b) able to create solutions to problems in everyday life [63], [64], and (c) students become more active and enthusiastic [65]. In the future, research on calculus learning can be directed to various aspects that aim to improve learning outcomes and are also linked to efforts to stimulate student interest in learning, career interest, creating jobs in the STEM field, and others.

\section{Conclusions}

This research is a research \& development research focusing on the trial aspect to see the level of validity, practicality, and effectiveness of the calculus learning model with the STEM approach for students. Based on the research data analysis results, this learning model is declared valid, practical, and effective by conducting a series of trial activities involving experts, lecturers, and students. The level of validity of this learning model is obtained through validation tests with two experts. The results of the two experts' assessment stated that the cumulative average score was in the valid category so that it could be continued for trials with users (lecturers \& students). Furthermore, this learning model's level of practicality is determined through three types of activities, namely monitoring the implementation of the model, lecturer response questionnaires, and student response questionnaires. This calculus learning model's practicality was stated to be good because the responses received from lecturers were positive responses. In addition to the validity and practicality level, this learning model is also tested for its effectiveness through learning outcomes tests (pretest and posttest). The statistical effectiveness test shows that there is a difference in the mean score between the pretest and posttest. Thus, the calculus learning model with the STEM approach is proven effective in improving student learning outcomes.

\section{Acknowledgements}

The author would like to thank the Indonesian Christian University (UKI) Toraja and Makassar State University, Indonesia, for supporting this research process. Also, the authors thank the Indonesian Ministry of Education \& Culture for providing support by providing research assistance through the BPDN Scholarship program.

\section{REFERENCES}

[1] K. Peterman, J. L. Daugherty, R. L. Custer, and R. J, M, "Analysis the Integration of Engineering in Science Lessons with the Engineering-infused Lesson Rubric," Journal of Science Education, vol. 39, no. 14, pp. 19331931, 2017.

[2] J. Hallstrom and K. J. Schonborn, "Models and Modelling for Authentic STEM Education: Reinforcing the Argument," International Journal of STEM Education, vol. 6, no. 1, 2019. https://doi.org/10.1186/s40594- 019-0178-Z

[3] D. E. Proudfoot and M. Kebritchi, "Scenario-based Elearning and STEM Education: A Qualitative Study Exploring the Perspectives of Educators," International Journal of Cognitive Research in Science, Engineering and Education, vol. 5, no. 1, pp. 7-18, 2017. https://doi.org/10.5937/IJCRSEE1701007P

[4] Organization for Economic Cooperation and Development (OECD), Assessing Scientific, Reading, and Mathematical Literacy. Paris: OECD, 2006.

[5] N. Erdogan, B. Navruz, R. Younes, and R. M. Capraro, "Viewing How STEM Project-based Learning Influences Students' Science Achievement through the Implementation Lens: A Latent Growth Modeling," Eurasia Journal of Mathematics, Science and Technology Education, vol. 12, no. 8, pp. 2139-2154, 2016. https://doi.org/10.12973/eurasia.2016.1294a

[6] R. Lamb, T. Akmal, and K. Petrie, "Development of a 
Cognition-priming Model Describing Learning in a STEM Classroom," Journal of Research in Science Teaching, vol. 52, no. 3, pp. 410-437, 2015. https://doi.org/ $10.1002 /$ tea. 21200

[7] J. L. Fitzakerley, M. L. Michin, J. Patin, and J. M. Dubinsky, "Neuroscientists' Classroom Visits Positively Impact Student Attitudes," PLoS One, vol. 8, no. 12, pp. 1-14, 2013. https://doi.org/10.1371/journal.pone. 0084035

[8] D. Yang and S. J. Baldwin, "Using Technology to Support Student Learning in An Integrated STEM Learning Environment," International Journal of Technology in Education and Science, vol. 4, no. 1, pp. 1-11, 2020. https://doi.org/10.46328/ijtes.v4i1.22

[9] S. D. McCaslin, "The Influence of STEM in Initiative for Middle and High School Students on Female STEM College Major," Capella University, Minnesota US, 2015.

[10] H. Salzman, "What Shortages? The Real Evidence about the STEM Workforce," Issues in Science and Technology, vol. 29 , no. 4 , pp. 58-67, 2013.

[11] N. C. Siregar, R. Rosli, S. M. Maat, and M. M. Capraro, "The Effect of Science, Technology, Engineering and Mathematics (STEM) Program on Students' Achievement in Mathematics: A Meta-Analysis," International Electronic Journal of Mathematics Education, vol. 15, no. 1, pp. 1-12, 2020. https://doi.org/10.29333/iejme/ 5885

[12] P. Parmin and S. Sajidan, "The Application of STEM Education in Science Learning at Schools in Industrial Areas," Journal of Turkish Science Education, vol. 16, no. 2, pp. 278-289, 2019. https://doi.org/10.12973/ tused.10281a

[13] N. Z. Chesky and M. R. Wolfmeyer, Philosophy of STEM Education. New York: Palgrave Macmillan, 2015.

[14] A. Gomez and B. Albrecht, "True STEM Education," Technology \& Engineering Teacher, vol. 73, pp. 8-16, 2013.

[15] K. C. Margot and T. Kettler, "Teachers' Perception of STEM Integration and Education: A Systematic Literature Review," International Journal of STEM Education, vol. 6, no. 2, pp. 1-16, 2019. https://doi.org/10.1186/s40594-018$0151-2$

[16] N. Idris, "Enhancing Students' Understanding in Calculus through Writing," International Electronic Journal of Mathematics Education, vol. 4, no. 1, pp. 36-55, 2009.

[17] N. F. Magsino, "Computational Competence on Basic Calculus of STEM Students through Mathematical Games," Asia Pasific Journal of Education, Arts, and Science, vol. 5, no. 3, pp. 59-65, 2018.

[18] L. Smolinsky, G. Olafsson, B. D. Marx, and G. Wang, "Online and Handwritten Homework in Calculus for STEM Majors," Journal of Educational Computing Research, vol. 57, no. 6, 2019. https://doi.org/10.1177/0735633118800808

[19] N. C. Barroso, "Mathematical Models in Predictig Retention of STEM Students in Pre-Calculus," International Journal of Pedagogical Development and Lifelong Learning, vol. 1, no. 1, pp. 1-6, 2020.

[20] Y. Li and A. Schoenfeld, "Problematizing Teaching and Learning Mathematics as 'Given' in STEM Education," International Journal of STEM Education, vol. 6, no. 44, pp.

\section{1-13, 2019. https://doi.org/10.1186/s40594-019-0197-9}

[21] S. Sulistiawati, D. Juandi, and R. Yuliardi, "Pembelajaran Terintegrasi STEM untuk meningkatkan Literasi Matematis Mahasiswa Calon Guru Matematika pada Perkuliahan Pra-Kalkukus 1," Teorema: Teori dan Riset Matematika, vol. 6, no. 1, pp. 82-97, 2021.

[22] H. Helaluddin, M. A. Ahmad, and A. Anshari, "Need Analysis of Academic Writing Teaching Model Based on Process-genre Approach: What Do They Really Need?," Universal Journal of Educational Research, vol. 8, no. 10, pp. 4728-47355, 2020. https://doi.org/10.13189/ujer.2020. 081043

[23] D. J. Cothran, P. H. Kulinna, and D. A. Garrahy, "This is Kind of Giving a Secret Away: Students' Perspective on Effective Class Management," Teaching and Teacher Education, vol. 19, no. 4, pp. 435-444, 2003.

[24] T. Supartini, I. T. J. Weismann, H. Wijaya, and H. Helaluddin, "Development of Learning Methods through Songs and Movements to Improve Children's Cognitive and Psychomotor Aspects," European Journal of Educational Research, vol. 9, no. 4, pp. 1615-1633, 2020. https://doi.org/10.12973/eu-jer.9.4.1615

[25] D. Henrikson, "Full STEAM Ahead: Creativity in Excellent STEM Teaching Practices," The STEAM Journal, vol. 1, no. 2, 2014. https://doi.org/10.5642/steam.20140102.15

[26] M. Biasutti and H. El-Deghaidy, "Interdisciplinary Project-based Learning: "An Online Wiki Experience in Teacher Education," Technology, Pedagogy, and Education, 2014. https;//doi.org/10.1080/1475939X.2014899510

[27] H. El-Deghaidy and N. Mansour, "Science Teachers' Perceptions of STEM Education: Possibilities and Challenges," International Journal of Learning and Teaching, vol. 1, no. 1, pp. 51-54, 2015. https://doi.org/ 10.18178/ijlt.1.1.51-54

[28] N. Baharin, N. Kamarudin, and U. K. A. Manaf, "Integrating STEM Education Approach in Enhancing Higher Order Thinking Skills," International Journal of Academic Research in Business Social Science, vol. 8, no. 7, pp. 810-822, 2018.https://doi.org/10.6007/IJARBSS/v8-i7 $/ 4421$

[29] M. Stohlmann, T. Moore, and H. G. Roehrig, "Consideration for Teaching Integrated STEM Education," Journal of Pre-college Engineering Education Research, vol. 2, no. 1, 2012. https://doi.org/10.5703/1288284 314653

[30] N. Olivarez, "The Impact of a STEM Programme on Academic Achievement of Eight Grade Students in a South Texas Middle School," Texas A \& M University, 2012.

[31] S. Olusegun, "Constructivism Learning Theory: A Paradigm for Teaching and Learning," IOSR Journal of Research and Method Education, vol. 5, no. 6, pp. 165-174, 2015. https:doi.org/10.12973/eurasia.2014.1073a

[32] E. H. M. Shahali, L. Halim, S. Rasul, K. Osman, Z. Ikhsan, and F. Rahim, "Bitara-STEM Training of Trainers' Programme: Impact on Trainers' Knowledge, Beliefs and Efficacy towards Integrated STEM Teaching," Journal of Baltic Science Education, vol. 14, no. 1, pp. 85-95, 2015.

[33] J. V. Ernst, T. O. Williams, A. C. Clark, D. P. Kelly, and K. 
Sutton, "K-12 STEM Educator Autonomy: An Investigation of School Influence and Classroom Control," Journal of STEM Education, vol. 18, no. 5, pp. 5-9, 2018.

[34] J. P. Vulperhorst, K. R. Wessels, A. Bakker, and S. F. Akkerman, "How Do STEM-interest Students Pursue Multiple Interests in Their Higher Educational Choice?," International Journal of Science Education, vol. 40, no. 8, pp. 828-846, 2018. https:doi.org/10.1080/09500693.2018. 1452306

[35] T. J. Moore and K. A. Smith, "Advancing The State of The Art of STEM Integration," Journal of STEM Education: Innovations and Research, vol. 15, no. 1, pp. 5-10, 2014.

[36] N. Nieveen, "Prototyping to Reach Product Quality," in Design Approaches and Tool in Education and Training, J. Van Den Akker, R. M. Branch, K. Gustafson, and Nienke Nieveen, Eds. London: Kluwer, 1999.

[37] P. Ghauri and K. Gronhaug, Research Methods in Business Studies. Harlow: Prentice Hall, 2005.

[38] A. P. Field, Discovering Statistic Using SPSS. Newbury Park: Sage Publication, 2005.

[39] H. Taherdoost, "Validity and Reliability of Research Instrument: How to Test the Validation of a Questionnare/survey in a Research," International Journal of Academic Research in Mangement, vol. 5, no. 3, pp. 2836, 2016.

[40] M. Zulkifli, "Model of Learning Information and Communication Technology Based: Study of Learning Islamic Education at Senior High School 4 Kendari," IOSR Journal of Research \& Method in Education, vol. 3, no. 1, pp. 24-27, 2013.

[41] J. S. Kadir, M. Zaim, and R. Refnaldi, "Developing Instruments for Evaluating Validity, Practicality, and Effectiveness of the Authentic Assessment for Speaking Skill at Junior High School," in Andvances in Social, Education, and Humanities Research (6th International Conference on English and Teaching), 2018.

[42] H. Hasmawaty, H. Syam, and A. Saman, "Validity, Practicality, and Effectiveness: The Last Step in Development of Entrepreneurship Education Based Role-Playing for Kindergarten," Universal Journal of Educational Research, vol. 8, no. 12, pp. 8092-8101, 2020. https://doi.org/10.13189/ujer.2020.082611

[43] T. Z. Mutakin, "Analisis Kesulitan Belajar Kalkulus 1 Mahasiswa Informatika," Formatif: Jurnal Ilmu Pendidikan MIPA, vol. 3, no. 1, pp. 49-60, 2015. https:doi.org/10.30998/formatif.v3i1.113

[44] R. Aditia, B. Susilo, and E. P. Purwandari, "Media Pembelajaran Kalkulus Berbasis Web,"Jurnal Rekursif, vol. 5, no. 3, 2017.

[45] M. Afandi, E. Chamala, and O. P. Wardi, Model dan Metode Pembelajaran di Sekolah. Semarang: Unissula Press (Universitas Islam Sultan Agung Semarang), 2013.

[46] S. S. Ellis, Model of Teaching: A Solution to the Teaching Style/Learning Style Dillema. Greenwich Connecticut: The Association for Supervision and Curriculum, 1979.

[47] B. Joyce, M. Weil, and E. Calhoun, Models of Teaching, Delapan. Yogyakarta: Pustaka Pelajar, 2011.
[48] K. Y. Tung, Desain Instruksional: Perbandingan Model dan Implikasinya. Yogyakarta: Andi Publisher, 2016.

[49] A. S. Ahmar and A. Rahman, "Development of Teaching Material Using An Android," Global Journal of Engineering Education, vol. 19, no. 1, 72-76, 2017.

[50] W. Yahya, M. Munoto, and S. Soeryanto, "Inovasi Perangkat Pembelajaran Sistem Kelistrikan Otomotif untuk Meningkatkan Hasil Belajar Siswa," Jurnal Pendidikan Vokasi: Teori \& Praktik, vol. 2, no. 2, 1-21, 2014.

[51] S. Azwar, Penyusunan Skala Psikologi. Yogyakarta: Pustaka Pelajar, 2012.

[52] D. V. Rogayan Jr. and L. F. Dollete, "Development and Validation of Physical Science Workbook for Senior High School," Science Education International, vol. 30, no. 4, pp. 84-290, 2019. https://doi.org/10.33828/ sei.v30.i4.5

[53] M. Muhali, L. Yuanita, and M. Ibrahim, "The Validity and Effectiveness of the Reflective-metacognitive Learning Model to Improve Students' Metacognition Ability in Indonesia," Malaysian Journal of Learning and Instruction, vol. 16, no. 2, pp. 33-74, 2019. https://doi.org/10.32890/m jli2019.16.2.2

[54] T. Plomp, Educational Design Research: An Introduction. Enschede: Netherlands Institute for Curriculum Development, 2013.

[55] A. Jaedun, V. L. Hariyanto, and N. E. Raharjo, "Pengembangan Model Pembelajaran Produktif Bermuatan Kewirausahaan," Jurnal Kependidikan, vol. 1, no. 1, pp. 125-138, 2017.

[56] H. Hamdan, "Model Pengembangan Kreativitas dan Inovasi dalam Membentuk Entreperneur di Era Ekonomi Digital," Jurnal Manajemen Kewirausahaan, vol. 7, no. 1, pp. 59-68, 2019.

[57] L. Mardhiyatirrahmah, M. Muchlas, and M. Marhayati, "Dampak Positif dan Faktor-faktor yang Mempengaruhi Penerapan Pendekatan STEM pada Pembelajaran Matematika di Sekolah," Jurnal Pendidikan Matematika, vol. 6, no. 2, pp. 78 - 88. 2020. https://doi.org/10.33474/jp m.v6i2.5299.

[58] E. Susanti and H. Kurniawan, "Design Pembelajaran Matematika dengan Pendekatan STEM (Science, Technology, Engineering, Mathematics)," AKSIOMA: Jurnal Matematika dan Pendidikan Matematika, vol. 11, no. 1, pp. 37-52, 2020. https://doi.org/10.26877/aks.v11i1.52 92.

[59] C. L. Chiang and H. Lee, "The Effect of Project-based Learning on Learning Motivation and Problem-solving Ability of Vocational High School Students," International Journal of Information and Education Technology, vol. 6, no. 9, pp. 709-712, 2016. https://doi.org/10.7763/ijiet.2016 .v6.779

[60] M. Ong, J. M. Smith, and L. T. Ko, "Counterspaces for Women of Color in STEM Higher Education: Marginal \& Central Spaces for Persisteance and Succes," Journal of Research in Science Teacing, vol. 55, no. 2, pp. 206-245, 2017. https://doi.org/10.1002/tea.21417

[61] M. R. Connolly, Y. G. Lee, and J. N. Savoy, "The Effects of Doctoral Teaching Development on Early-career STEM 
Scholars? College Teaching Self-efficacy," Life Science Education, vol. 17, no. 1, pp. 1-15, 2018. https://doi.org/10.1187/cbe.17-02-0039

[62] K. Herdem and I. Unal, "Analysis of Studies about STEM Education: A Meta-synthesis Study," Journal of Educational Science, vol. 48, no. 48, pp. 145-163, 2018. https://doi.org/10.15285/marvaebd.381417.

[63] S. Gulen, "Determination the Effect of STEM Integrated Argumentation-based Science Learning Approach in Solving Daily Life Problems," World Journal on Educational Technology: Current Issues, vol. 10, no. 4, pp.
95-114, 2018.

[64] S. Gulen and S. Yaman, "Argumentation Process and Use of STEM Disciplines in Science Lesson: Focus Group Interview," YYU Journal of Education, vol. 15, no. 1, pp. 1184-1211, 2018. https://doi.org/10.23891/efdyyu2018.10 1

[65] E. Susanti and H. Kurniawan, "Desain Pembelajaran Matematika dengan Pendekatan STEM (Science, Technology, Engineering, Mathematics)," AKSIOMA: Jurnal Matematika dan Pendidikan Matematika, vol. 11, no. 1, pp. 37-45, 2020. 